\title{
Differences in Fathering among Russian Men Brought up with and without a Father
}

\author{
Julia V. Borisenko*, Elena V. Evseenkova \\ Kemerovo State University, Kemerovo, Russia \\ *Corresponding author. E-mail: evseenkova@mail.ru
}

Background. In this article, we present the results of a study on the fathering characteristics of Russian men, in early and middle adulthood, brought up with and without a father. There is a theory that fathering practices are determined both by early childhood experiences, as well as by marital relationships in adulthood, because of the links between co-parenting and fathering. Thus, we hypothesize that the fathering characteristics of men in early and middle adulthood, brought up with and without a father, will be different.

Objective. We studied the characteristics of fathering and marital satisfaction in middle adulthood among Russian men brought up without a father, who suffered from paternal deprivation in childhood.

Design. Ninety married men (48 fathers who experienced paternal deprivation in childhood and 42 men brought up in two-parent families) were assessed on a number of measures.

Results. The statistical analysis of the data, including descriptive statistics, t-test and correlation analysis, let us distinguish between the two groups of fathers. Significant t-test differences between the two groups were found in caregiving identity, breadwinning identity, attitudes towards parenting, and marital satisfaction. Also, men brought up in paternally deprived homes, unlike the men from two-parent families, were more likely to indicate difficulties with father-child relationships and gender role conflict in parenting, and give greater relevance to their female partners' attitudes and expectations towards their fathering.

Conclusion. The lack of a father's influence on men in childhood strengthens the influence of marital relationships on fathering, in maturity.

\section{Keywords:} fathering, paternal deprivation, marital satisfaction, caregiving identity, breadwinning identity 


\section{Introduction}

The importance and complexity of issues surrounding fathering, and rising practical demand has resulted in sustained academic attention on fathering over the years (Parke, 2002; Goldberg, Tan \& Thorsen, 2009). The psychological and sociological issues surrounding fathering practices have been studied in detail. There are two principal approaches to studying fathering, depending on where the research starting point is - on the child or the father (Ovcharova, 2003). The first approach opens the door to many interesting studies of the direct influences (father to child) and indirect influences (via its effects on mothers (Scoblo, Baz, Lukovceva, 2004) and siblings, or reciprocal influences between fathers and children (Pleck, 2010b)), and the effects of paternal involvement on different child outcomes such as: child's intellectual, emotional, and financial well-being (Sigle-Rushton \& McLanahan, 2004; Miller, 2013; Eggebeen \& Knoester, 2001; DePasquale, et al., 2016).

Russian researchers (Filatova, 2010; Bezrukova, 2013; Kon, 2009) consider that the father is also responsible for the social status of the family during the child's early years and adolescence. Any problems in the father-child relationship may have a negative impact on the child (Fthenakis, 2004; Kon, 2009; Pleck, 2010b), manifesting in emotional problems in children of one-parent families (Sigle-Rushton \& McLanahan, 2004), less material security (Gurko, 2003), or development risks, because of the processes hypothesized by attachment theorists (Kotelchuck, 1976; Lamb, 2002), who consider father involvement critical to promote secure infant attachment, which leads to good outcomes for the child. Though the attachment theory does not explain paternal influences on older children, and on adolescents, or on the quality of the relationship between older fathers and adult children (Polenick, DePasquale, Eggebeen, Zarit, \& Fingerman, 2016), it provides the basis for interpreting why paternal involvement leads to positive developmental outcomes for the child, and mediation of the association between the father's presence and child outcomes through paternal involvement (Carlson, 2006), and the association between the father-son relationship and male mental health (Miller, 2013) or gender identity (Pleck, 2010a). So the unique role that a father's influence plays on child development is now well recognized (Amato \& Rivera, 1999; Fagan, 2016; Pleck \& Masciadrelli, 2004; McBride, Dyer \& Laxman, 2009).

Studies on the second approach focus on the development of parenting skills in men (Belsky, 1984, Volling \& Belsky, 1991; Woodworth, Belsky \& Crnic, 1996), exploring the actual meaning of fathering to a man (Eggebeen \& Knoester, 2001), studying the association between fathering and masculinity as it was referred to above (Pleck, 2010a), and also analyzing such factors of paternal involvement (the phenomenon theoretically conceptualized by Lamb, 2002; Pleck, 1997; Palkovitz, 2002; Pleck \& Hofferth, 2008) as marital satisfaction directly correlated with paternal involvement (DeLuccie, 1996), or marital conflict which is negatively correlated with paternal involvement (Doherty, Boss, LaRossa, Schumm \& Steinmetz, 1993), and family relations across generations as a model for fathering (Eggebeen \& Knoester, 2001), factors of psychological readiness for fathering (Ovcharova, 2003). In the overlap between these two approaches lies the issue of the influence of father-son attachment during infancy on the adult son's fathering (Bailey, 1992; Kon, 2009). Although there are a lot of studies defining the father's influence on a child's 
gender-typed behavior (Amato, \& Rivera, 1999; Deutsch, Servis \& Payne, 2001; Coley, Votruba-Drzal, \& Schindler, 2009; Pleck, 2010a) and some studies proving that the mother-daughter attachment during early infancy determines daughter's mothering and her attachment to her baby (Brutman, Pankratova \& Enikopolov, 1994; Filippova, 2002) such an effect of father-son attachment on the son's own fathering practices in adulthood, has not yet been well understood.

In Russia, this is a particularly relevant issue for historical reasons, as is the influence of social attitudes on male roles in general, and fatherhood in particular. Since Bronfenbrenner's (1970) early work paid attention to the differences between Russian and US socialization models, a number of studies have assessed aspects of Russian family life and child development (Gurko, 1997; Utrata, 2008; Nelson, et al., 2010; Nelson, et al., 2014; Podkladova, 2016). During the last thirty years, family roles in Russia have dramatically changed in keeping with the economic, social, and religious changes in the country. Having long been de jure, equal in rights with men, Russian women de facto were (and in some points are nowadays) more involved in the running of the household and have most of the responsibility for their children's upbringing, even in two-parent families (Antonov, 1998). Moreover, modern Russian women are not any less interested than Russian men in their professional careers, self-realization, and personal comfort (Biryukova \& Tyndik, 2014; Borisenko, 2016). As a result of this conflict, the value of parenthood in contemporary Russia is being replaced with non-family values. (Dobrykov, 2010).

Contemporary Russian families belong to a "modernized" family unit that demonstrates planned reproductive behavior and proclaims equal rights and obligations in breadwinning and childcare (Antonov, 1998; Dobrykov, 2010). Nonetheless, the inequality in employment and payment for the same work between men and women results often in a man becoming the foremost but not the only breadwinner for the family, and traditional attitudes towards the female role ensure that women end up with the responsibility of housework (Ashwin \& Lytkina, 2004) and childcare. This double employment continuing during the modernization of the Russian family unit results in women demanding greater male involvement in family life and, in particular, in parenting (Gurko, 2003; Radosteva, 2013). This leads to marital conflicts (Ashwin \& Lytkina, 2004), especially in the case when spouses have different attitudes towards childcare due to the differences in (or the absence of) parenting models in their own upbringing during childhood. Besides this, increased socioeconomic pressures and the fathers' beliefs about the irrelevance of nonresident fatherhood in Russia, push many fathers into disappearing altogether from their child's life (Gurko, 2003; Utrata, 2008). And, when the man has experienced the very same situation in his own childhood, the probability of such behavior increases (Gurko, 2003). Our study may therefore, expand our understanding of the fathering beliefs and practices among this group of men. And the results provided in this paper may be interesting to family therapists and family psychologists, as well as to family researchers studying fathering all over the world, providing opportunities for cross-cultural comparison and interpretation. 


\section{Paternal Influences}

The unique role that fathering plays on impacting child outcomes is well studied (Palkovitz, 2002; Pleck, 2010b; Rominov, Giallo, Whelan, 2016). Even before a child's birth, the father has an impact on his/her development's through providing favorable conditions for the pregnant woman (Scoblo, Baz, Lukovceva, 2004; Bouchard, 2012). Later, the father provides development for a child's motility, spatial orientation, physical skills (Doucet, 2009; El-Shadan, Schluter, 2015); which is an important factor for the child's intellectual development (Jeynes, 2015; Varghese, Wachen, 2016) as it was proved in T. A. Dumitrashku's study covering 120 children, 9-10 years old, from 60 Russian families (Dumitrashku, 1996). Also, identification with the father is the most important factor in the assimilation of moral standards and social and gender roles, especially for boys (Kon, 2009; Zakharova, 2011).

While fathering has a direct effect on shaping sons' gender-typed behavior, the most important determinant of male identification for the boy are: 1) father dominance, and 2) father involvement. The association between paternal masculinity orientation and paternal involvement also influences child outcomes (Pleck, 2010a) because a father's masculinity orientation can have a direct and indirect influence on his parenting, as long as the more masculine father demonstrates different behavior in parenting than a less masculine one. Also, a father's masculinity orientation can directly influence his child, when the son takes his father's masculinity orientation as a direct model for his behavior and/or self-esteem (Pleck, 2010a). If the father-son attachment is safe and their interactions are warm, the desire to be as "male" as the father considerably strengthens positive perceptions and attitudes, specifically about men's roles and the development of male behavior and identity (Kon, 2009; Zakharova, 2011).

Paternal absence influences many children living in one-parent families. If there is neither an auxiliary, nor a counterbalancing influence of the father, the value of the mother's identity and mother effects becomes much higher than usual (Wainright, \& Patterson, 2008; Kon, 2009). One more important factor in such a case is the absence of social confidence or stability and social security. A father's employment usually represents the real and symbolic status of the family, providing the basis for the economic progress of a family and providing security and confidence - at least in modern Russian reality (Gurko, 2003).

Also the father represents for boys the most natural source of knowledge about the world, work, equipment, etc., influencing their orientation towards their future professions, and developing socially useful purposes, ideals and behavior. That is why fatherless boys growing up without gender modeling are less successful in the resolution of conflicts, in the solution of cognitive tasks, and have particular difficulties in developing masculinity orientation and demonstrating male behavior (Bezrukova, 2013; Evans, 2017). Furthermore, a social environment where the boy (young man) since early childhood meets female behavioral models much more than male ones, as it usually occurs in Russian kindergartens and schools (Kletsina, Chikalova, 2013), complicates the issue even more. Not having gender-typed male role models, a boy can imitate female behavior (as demonstrated by mothers, grandmothers, and teachers) and may grow up to be soft and sensitive. Or, he could go the other way in supposing that a male's behavior is the opposite of female behavior. Thus, instead of adopting a female's social normativity and avoidance of 
addictions he could demonstrate contrary behavior leading to alcohol abuse, drug addiction and/or deviance (Kon, 2009). Therefore the importance of the modeling effect of male gender-typed behavior (provided by the father, the grandfather, or by the sports trainer) on boys' behavior is undoubted (Kletsina, Chikalova, 2013).

Consequently, if the fathering of an adult man is part of a male gender role interconnected with his masculinity orientation (Pleck, 2010a), it is influenced too, by the fathering modeling from the man's own early childhood. However, the studies of parents' gender influence (Biblarz \& Stacey, 2010; Tasker, 2010) demonstrate that it's not the parents' gender alone but the parents' involvement and parenting practices as well, that influence a child's behavior. So, the relationship between the man and his own father in childhood, and also his father's behavior patterns and his attitudes towards masculinity, may be important determinants of the man's relationships with his own child (Ovcharova, 2003; Zakharova, 2011; Miller, 2013). This has also been confirmed by R. C. Fraley and P. R. Shaver (2000) by assessing the similarity between one's attachment styles with different people in one's life from infancy to adulthood. Where broken relationships with the father have led to unsafe attachment - such a modeling effect either is absent or is negative - how this influences a man's fathering practices, has not yet been well examined. We hypothesize that there may be difficulties with the father-child relationship due to his unsafe attachment since childhood or his attempting to play a mother's role, stemming from the strong attachment to his mother in his own childhood - taking unclear parenting as a model.

\section{Influence of Marital Relationships}

The majority of modern studies claim that parenting is not just a personal phenomenon (Miller, 1986) because of its interconnection with the marital relationships (Erel \& Burman, 1995; Pleck, 2010b; Bouchard, 2012). In academic studies that research fathering practices, the mother is considered to be the father's copartner who, in many ways, defines the father's behavior. Father involvement studies view the father-child relationship as embedded in a broader pattern of family interaction (Pleck, 2010a). The father's involvement is proved to be influenced by the mother's involvement as long as more involved mothers force their partners to also be more involved in their child's life (Pleck\& Hofferth, 2008). Moreover, J. Pleck and S. Hofferth have postulated that parental identity can be defined only in close interrelation with a partner's actual and perceived reflected-appraisal (Pleck \& Hofferth, 2008). Thus, a man's fathering is closely associated with an appraisal of his wife as a mother and with her expectations for his fathering and male behavior. Her own maternal identity is also connected with her husband's attitudes towards the mother-role and the priority of a woman's career over her role as a caregiver for her children. In addition, the smaller the role a father plays in a child's life, the stronger the economic, social, and psychological stress a woman undergoes, which leads to a different set of family conflicts, and the risk of divorce (Radosteva, 2013).

Thus, a man's fathering is closely connected 1) to his relationship with own father who provided a masculine model for the growing man through his childhood (Pleck, 2010a) and, 2) with his own marital relationships (Roskam, 2016; Kwan, 
Kwok, Ling, 2015), where male gender-typed behavior is realized and transformed. We believe that due to having an unsafe attachment to his father (Fraley \& Shaver, 2000) and/or absence of male gender-typed model leading to the unclear masculinity orientation (Kletsina, Chikalova, 2013), paternal deprivation in a man's childhood may complicate, in some ways, marital relations in his own marriage, which cannot but complicate the father-child relationship as well. In this case, the attitudes and expectations of a female partner towards a man's behavior become more relevant than his own unclear masculinity model. It may cause additional tension, both in the child-parent and in marital relations in such a man's family.

Here, the influence of the marital relationship on fathering may be the potential difference between fathers who have grown up with or without a father in their family of origin. In this way, we define the scientific issue of this study: to examine whether the fathering practices of men who did not have a father, or any close male figure, in childhood, differ from the fathering practices of men brought up in two-parent families. Such a study will fill some gaps in our knowledge about the development of parenting skills in men by focusing on this particular context. So, the goal of this study is to find out the fathering specifics of men who grew up in paternal deprivation. Bearing in mind these issues, we put forward:

Hypothesis: The men brought up in paternal deprivation, unlike men brought up in two-parent families, may 1) have different attitudes towards parenting and experience difficulties with the father-child relationship; and 2) be are more likely to attempt to play a mother-role for their children and may also give more weight to the attitudes and expectations of their female partners towards masculine behavior, compared to fathers raised in two-parent families.

\section{Methods}

\section{Sample}

Ninaty Russian fathers were the focus of this study. They were divided into two groups. Forty eight men who experienced paternal deprivation in childhood for any reason (divorce, abandonment, unwed mother, etc.) were in the first group. Forty two men raised in two-parent families formed the second group. The respondents were recruited and compensated through the local Research community. A 30-minute, face-to-face, baseline survey interview was conducted between December 2013 and September 2017. This gathered data on the basic characteristics of the respondents: aspects of demographic information; family background; employment and educational characteristics, as well as some data about their spouses. After that, all men were asked to answer the questionnaires. The groups were equal in age, education, social status, and marital status (Table 1). The average age of the men was 32 years $(S D=3.3)$, with a mean education level of 14.0 years $(S D=2.2)$. Men of this age were chosen because this age is more typical and productive for the creation of a family and the birth of children, i.e., acceptance of a father role. All the participants were living in the Kemerovo Region in Russia. Sixty six percent were from urban families from the cities of Kemerovo, Novokuznetsk, Belovo and Mariinsk; 36\% were from rural families. All participants were married. Ninety eight percent of the fathers in the first group were employed, as were $95 \%$ of those in the 
second group. The average number of children per family was $2.0(\mathrm{SD}=0.9)$ and the average age of a child was 7 years $(S D=0.9)$. Firty percent of the participants had one child, $68 \%$ of men had two children, $2 \%$ had three or more children (if the father had more than one child, we collected data about the oldest child.) Of the children, $58 \%$ were boys and $42 \%$ were girls.

Table 1

Main respondent characteristics of fatherless fathers and fathers brought up in two-parent families in Russia, $N=90$

\begin{tabular}{|c|c|c|c|}
\hline Respondent characteristics & All men & $\begin{array}{l}\text { Fathers brought } \\
\text { up in one-parent } \\
\text { families }\end{array}$ & $\begin{array}{c}\text { Fathers brought } \\
\text { up in two-parent } \\
\text { families }\end{array}$ \\
\hline Average age (years old) & 32 & 32.3 & 31.7 \\
\hline \multicolumn{4}{|l|}{ Permanent residence $(\%)$} \\
\hline Town & 64 & 63 & 65 \\
\hline Country & 36 & 37 & 35 \\
\hline \multicolumn{4}{|l|}{ Education (\%) } \\
\hline High school diploma & 18 & 19 & 17 \\
\hline College attendance & 41 & 42 & 40 \\
\hline Bachelor's degree & 32 & 31 & 33 \\
\hline Graduate degree & 9 & 8 & 10 \\
\hline Married (\%) & 100 & 100 & 100 \\
\hline Employment (\%) & 97 & 98 & 95 \\
\hline \multicolumn{4}{|l|}{$\begin{array}{l}\text { Average number of children } \\
\text { per man }\end{array}$} \\
\hline One child (\%) & 30 & 31 & 29 \\
\hline Two children (\%) & 68 & 67 & 69 \\
\hline Three or more children (\%) & 2 & 2 & 2 \\
\hline Average age of child (years old) & 7 & 7.1 & 6.9 \\
\hline $\begin{array}{l}\text { Average age at first childbirth } \\
\text { (years old) }\end{array}$ & 26 & 25 & 27 \\
\hline \multicolumn{4}{|l|}{ Sex of the children } \\
\hline Boys (\%) & 58 & 59 & 57 \\
\hline Girls (\%) & 42 & 41 & 43 \\
\hline $\begin{array}{l}\text { Child with special needs } \\
\text { (Down's Syndrome) (\%) }\end{array}$ & 1.1 & 0 & 2.2 \\
\hline Spouse's employment (\%) & 72 & 73 & 71 \\
\hline \multicolumn{4}{|l|}{ Spouse's family of origin } \\
\hline One-parent families (\%) & 32 & 33 & 31 \\
\hline Two-parent families (\%) & 68 & 67 & 69 \\
\hline
\end{tabular}


Additionally, $1.1 \%$ of the fathers (1 out of 90 ) had a child with special needs (Down's Syndrome). None of the men in the first group had any kind of relationship with their biological fathers since early childhood (the last connection was on average at two years of age), and did not have a step-father or any constant male figure in their childhood.

\section{Measures}

Family characteristics were measured with a semi-structured interview specially developed for studying the relationship of the man with his partner and his parents. The relationship with the father, for all the respondents, was coded as paternal deprivation (0), conflict (1), stable (2), and warm (3).

Family context included parent-family characteristics (family status, relationships with the parents) and marital-family characteristics (the number of children in the family and marital conflict).

Marital conflict was assessed by the men's response to: How often do you argue with your partner? $(1=$ never, $2=$ once in a while, $3=$ often, $4=$ fairly often, $5=$ very often).

Gender role conflict was assessed by the men's response to: How often does the inconsistency of gender or parenting roles cause a quarrel in your family? $(1=$ never, $2=$ once in a while, $3=$ often, $4=$ fairly often, $5=$ very often).

Marital satisfaction was assessed by "The Marital Satisfaction Measure Instrument” (MSMI) of V. Stolin, T. Romanova, G. Butenko (quoted in Borisenko, 2011), which contains 20 statements about marital relations with three answer variants ( $1=$ agree, 2 = not sure, $3=$ disagree $)$.

Child characteristics including age and gender of the child (1 for male and 2 for female) and Father employment were assessed using scales, based on a semistructured interview that indicates father's employment and family status.

Father's attitudes, involvement and identity were measured with PARI (Parent Attitude Research Instrument of E.S. Schaefer and R.A. Bell (Schaefer \& Bell, 1958), CBIRAI (Caregiving and Breadwinning Identity and Reflected-Appraisal Inventory of J. Pleck, T.W. Maurer, H.R. Rane (Pleck, Maurer \& Rane, 2001) and some scales of a semi-structured interview. Respondents' attitudes towards parenting on the whole, and, fathering in particular, were assessed by PARI - a self-report questionnaire that assesses parental attitudes towards child-rearing and family life united into 23 scales, hypothesized to be relevant in child-rearing practices. They are: Encouraging Verbalization, Fostering Dependency, Breaking the Will, Fear of Harming Baby, Marital Conflict, Strictness, Irritability, Deification, Suppression of Aggression, Rejection of Homemaking Role, Equalitarianism, Approval of Activity, Inconsiderateness of Husband, Suppression of Sexuality, Ascendance of the Mother, Intrusiveness, Comradeship and Sharing, Dependence of Mother, Seclusion of Mother, Martyrdom, Irritability, Excluding Outside Influences, Avoidance of Communication, and Acceleration of Development. PARI contains 115 statements with the response format consisting of a 4-point scale (strongly agree, mildly agree, mildly disagree, strongly disagree).

Father parental identity and relevance of a female partner's expectations towards a man's behavior were assessed by CBIRAI. CBIRAI is a self-report questionnaire 
that has six sections (three for each of the two most significant parenting domains (caregiving and breadwinning) including respondents' parental identity (Caregiving Identity, Breadwinning Identity); the evaluations of their wives as mothers (Caregiving Reflected-Appraisal, Breadwinning Reflected-Appraisal), and the perceptions of their wives' evaluations for their fathering (Caregiving Perceived Reflected-Appraisal, Breadwinning Perceived Reflected-Appraisal).

Father involvement was assessed by the men's response to questions of a semistructured interview such as: How often does your child talk over important decisions with you? How often do you listen to your child's side of an argument? Do you feel close to your child? How often do you know who your child is with when he (she) is not at home? How often do you miss events or activities that are important to your child? How often do you share ideas or talk about what really matters to your child? How often do you spend time or play with your child? $(1=$ never, $2=$ once in a while, $3=$ often, $4=$ fairly often, $5=$ very often).

\section{Results}

Table 2 presents the results of the statistical analysis. The Student t-test with a Bonferroni-Holm correction was used to compare mean values between two groups. Statistics were calculated with a $5 \%$ significance level.

Comparison of the output data of this investigation with statistic normative values showed that the mean and standard deviation of the values of the PARI scales were within the range of normative values of this instrument. The mean and standard deviation of the values of the CBIRAI scales were comparable with the range of values showed by the authors (Maurer, Pleck \& Rane, 2001) and Russian translation and validation of values (Borisenko, 2013).

While analyzing the questionnaire output data, we found significant differences regarding parenting attitudes (Seclusion of mother, Martyrdom, Irritability, Excluding outside influences, Avoidance of communication; Acceleration of development, Parenting identity (Caregiving Reflected-Appraisal, Breadwinning Identity and Breadwinning Perceived Reflected-Appraisal). Also, family parameters such as gender role conflict, marital conflict, and the man's relationship with his father, varied in the two groups.

There were no statistically significant variances in the mean values of the following scale of PARI: Encouraging Verbalization, Fostering Dependency, Breaking the Will, Fear of Harming Baby, Marital Conflict, Strictness, Irritability, Deification, Suppression of Aggression, Rejection of Homemaking Role, Equalitarianism, Approval of Activity Inconsiderateness of Husband, Suppression of Sexuality, Ascendance of the Mother, Intrusiveness, Comradeship and Sharing, Dependence of Mother and some scales of CBIRAI (Caregiving Identity, Caregiving Perceived Reflected-Appraisal, Breadwinning Reflected-Appraisal) and statistically significant variances in the mean values of parenting involvement scales between the two groups were absent. Only the "feeling of closeness to a child" indicator was found to vary.

The men from the first group were found to demonstrate on a higher scale (than men of the second group), attitudes towards parenting such as claiming a male role (Seclusion of mother (PARI) which might be the result of absence of 
Table 2

Group characteristics of fathers brought up in one-parent and two-parent families ( $M, S D)$, and results of their statistical analysis $(t, p)$

\begin{tabular}{lcccc}
\hline \multicolumn{1}{c}{ Variable } & $\begin{array}{c}\text { Fathers brought } \\
\text { up in one-parent } \\
\text { families M (SD) }\end{array}$ & $\begin{array}{c}\text { Fathers brought } \\
\text { up in two-parent } \\
\text { families M (SD) }\end{array}$ & t-value & p \\
\hline CBIRAI: & & & & \\
Caregiving Reflected-Appraisal & $2.78(.375)$ & $2.54(.415)$ & -2.56 & .01 \\
Breadwinning Identity & $3.19(.467)$ & $3.65(.479)$ & 2.34 & .02 \\
Breadwinning Perceived Reflected- & $3.85(.634)$ & $3.12(.356)$ & 3.23 & .00 \\
Appraisal & & & & \\
PARI: & $13.79(.517)$ & $10.31(.490)$ & 1.52 & .00 \\
Seclusion of mother & $16.02(.347)$ & $10.95(.419)$ & 1.24 & .00 \\
Martyrdom & $13.91(.345)$ & $16.27(.698)$ & 2.24 & .03 \\
Irritability & $11.99(.478)$ & $15.89(.511)$ & 3.31 & .00 \\
Excluding outside influences & $15.28(.409)$ & $11.73(.450)$ & 2.13 & .04 \\
Avoidance of communication & $16.98(.398)$ & $12.74(.429)$ & -2.03 & .04 \\
Acceleration of development & & & & \\
INTERVIEW: & $3.00(.262)$ & $2.70(.290)$ & 1.29 & .01 \\
Marital conflict & $33.15(1.27)$ & $41.10(.988)$ & .19 & .85 \\
Marriage satisfaction & $3.30(.453)$ & $4.20(.399)$ & 3.15 & .00 \\
Feeling of closeness to the child & $4.64(.479)$ & $2.80(.402)$ & 2.13 & .00 \\
Gender role conflict & & & & \\
\hline
\end{tabular}

male role models in childhood), avoidance of communication with the child, and accentuation on martyrdom of parenting (PARI). They, less than fathers from the second group, desire the acceleration of child development and are less irritated with caregiving (maybe because they are more likely to attempt to play the mother's role for their children) and are more likely to admit extra-family influences on the child (PARI).

Greater avoidance of communication with the child and lower feelings of closeness to the child which were found in the first group could indicate difficulties with the father-child relationship, in the group of fathers brought up in one-parent families.

Also. some variances in paternal identity and marital relations were found between the two groups. The men brought up in single-mother families identified themselves with the breadwinner, more through marital relationships (higher than in second group level of Breadwinning Perceived Reflected-Appraisal) than through breadwinner identity (lower than in second group level of Breadwinning Identity which is hypothesized to be a mark of the male gender role), which might be interpreted as their inclination to consider the expectations of a female partner towards man's behavior as more relevant, than fathers brought up in two-parent 
families. Meanwhile, they value their wives less as mothers and are more likely to have marital conflict and a gender-role conflict in parenting (most likely, these could be interpreted as choosing between the maternal and paternal caregiving domains), which indicates an inclination to attempt to play a mother-role for their children.

A remarkable variance was found when we divided men from the first group according to their spouses' families of origin. Table 3 presents the variance between families with two spouses brought up without a father and families where only the man was brought up without a father. Husbands of wives who were also brought up in one-parent families were more likely to indicate marital and gender role conflicts and a lower level of marital satisfaction. The same variance regarding wives' families of origin in the group of men brought up in two-parent families were not found.

Table 3

Group characteristics (M, SD) of fathers brought up without a father, divided regarding their spouses' family of origin, and results of their statistical analysis $(t, p)$

\begin{tabular}{lcccc}
\hline \multicolumn{1}{c}{ Variable } & $\begin{array}{c}\text { Families with both } \\
\text { spouses brought } \\
\text { up without a father } \\
\mathbf{M}(\mathrm{SD})\end{array}$ & $\begin{array}{c}\text { Families with only } \\
\text { the man brought } \\
\text { up without father } \\
\mathbf{M} \text { (SD) }\end{array}$ & $\mathbf{t}$-value & $\mathbf{p}$ \\
\hline $\begin{array}{l}\text { INTERVIEW } \\
\text { Marital conflict }\end{array}$ & $3.11(.433)$ & $2.89(.400)$ & 1.19 & .01 \\
Gender role conflict & $4.81(.890)$ & $4.49(.345)$ & 3.12 & .00 \\
MSMI & $32.6(1.122)$ & $33.7(.899)$ & .11 & .05 \\
Marriage satisfaction & & & & \\
\hline
\end{tabular}

A deeper look at the correlation matrixes differential in the two groups helped to pinpoint strong correlations (with $\mathrm{p} \leq 0.01$ ) between marital satisfaction and parameters of co-parenting, such as Caregiving Reflected-Appraisal (.64) and Breadwinning Perceived Reflected-Appraisal (.72) in the group of men deprived of a father in childhood. For the fathers brought up in two-parent families, we could not find any significant correlations.

\section{Discussion}

The absence, or lack of male influence in childhood, may lead to an emergence of boys' difficulties in assimilating a gender role. In our study, most of the men deprived of fathers in their childhoods were more likely to have marital conflicts and gender role conflicts in parenting with regards to choosing between the maternal and paternal caregiving domains, and were likely to have difficulties with the father-child relationship. This is consistent with other findings and may be interpreted as the result of the emotional problems faced by children in one-parent families (see Sigle-Rushton \& McLanahan, 2004 and Fagan, \& Lee, 2016, for similar results) or insecure infant attachment with father (see Fraley \& Shaver, 2000 for 
comparable results). Also, this may be interpreted as a consequence of the violation of the gender role, due to the absence of father's own male role model since early childhood as indicated by I.S. Kon (2009) and E.I. Zakharova (2011).

Therefore, it can be concluded that men brought up without a father may face difficulties in taking on a male's role in marital relationships and fathering. Although this doesn't define the quality of fathering, it does demand a greater effort from the men while developing their own father-child relationships (Kon, 2009).

Thus, it can be said that fathering is influenced by the existence of a behaviormodel of one's own father. Men who were brought up in two-parent families have a clearer behavior model of what is called "doing family" (see Pleck, 2010b). However, all men in our sample were involved in varying degrees in their children's lives; therefore, the absence of a father's behavior-model does not preclude the ability to be a good father, but rather, influences the specifics of developing appropriate fathering practices due to a lack of male behavior-model since childhood. But the effects and risks of broken attachment raised more concerns, since fatherless fathers may feel less emotional closeness to their children (and, perhaps, to their partners) due to their early childhood experiences. This is consistent with the findings of G. Bouchard (2012), of the correlation between a man's childhood experiences and paternal engagement in adulthood. We have found differences in fathering between men brought up with or without a father in their family of origin. Fathers from oneparent families, differ from fathers raised in two-parent families in attitudes towards parenting, may have difficulties with the father-child relationship, are more likely to have gender-role conflict in parenting, and also give greater relevance to the attitudes and expectations of their female partner, than fathers from two-parent families

Our study helped to obtain evidence that fathering and the family role that these men develop has a close connection with their marital relationships. This corresponds with the concepts explored in the work of J. Pleck (Pleck, 2010b), who affirmed that a father's involvement in a child's life is directly influenced by the mother's involvement in the child's life. That is to say, the man's fathering is influenced not only by his relationship with own father in his childhood (Pleck, 2010a), but also by his marital relationships - which is also consistent with other findings (for instance, Pleck \& Hofferth, 2008; Roskam, 2016; Kwan, Kwok, Ling, 2015).

\section{Conclusion}

However, this study has raised more questions than answers and will be continued with more detailed research and a larger sample. It will be of great practical value in providing psychological assistance for young people entering into marriage, for pregnant couples and families with infants, as well as for children, adolescents and adults from one-mother families. Future research should seek to identify barriers that hinder young men from adopting good fathering practices; ways in which these barriers differ among groups of men; and strategies to successfully address these barriers. Finally, future research on parenting identity and behavior, and future theoretical models should include studying mechanisms by which co-parents can influence their partners' parenting identity and behavior. 


\section{Limitations}

Some limitations of the current study should be mentioned. First, for practical reasons, retrospective reports by adults of their own experiences in childhood were used to measure men's relationships with their fathers. Although retrospective reports have a worthwhile place in research, they are vulnerable to inaccurate recall and may involve substantial measurement errors. For instance, G. Bouchard (2012) cites a number of studies showing low levels of agreement between contemporaneous parental reports and retrospective recall by the children in adult life.

Second, all measures for this study relied on fathers' self-reports. In further studies, father engagement, for instance, could be evaluated using reports by external observers, such as the other parent. This will eliminate the influence of shared method variance in the evaluation of the relationships between the variables.

Third, the sample may have underrepresented fathers with more modest incomes or potentially less involved fathers. Adopted families and also non-resident fathers were also not represented. Finally, this study's use of a convenience sample limits the generalizability of results.

Despite these limitations, the current study furthers our understanding of the parenting practices of men brought up without a father, a sample that has too often been overlooked in previous studies. In addition, the current results reveal, as suspected by W. Doherty (1993), that in the study of fathers' engagement with their children, cohabitation and marriage should be part of the conversation.

\section{References}

Amato, P., \& Rivera, F. (1999). Paternal involvement and children's behavior. Journal of Marriage and the Family, 61, 375-384. https://doi.org/10.2307/353755

Antonov, A.I. (1998). Microsotsiologiya sem'i (metodologiya issledovaniya structur i protsessov) [Microsociology of the family (Methodology for studying structures and processes)]. Moscow: Nota Bene.

Ashwin, S. \& Lytkina, T. (2004). Men in Crisis in Russia: The Role of Domestic Marginalization. Gender and Society, 18(2), 189-206. https://doi.org/10.1177/0891243203261263

Bailey, W.T. (1992). Psychological development in men: Generativity and involvement with young children. Psychological Reports, 71, 929-930. https://doi.org/10.2466/pr0.1992.71.3.929

Bezrukova, O.N. (2013). Otcovstvo v transformirujutchemsja obtchestve: ozhidanija materei i praktiki otcov [Fathering in transforming society: mothers' expectations and fathers' practices]. Sozis, 11, 118-130. https://doi.org/10.3149/fth.1102.118

Biblarz, J.T. \& Stacey, J. (2010). How does the gender of parents matter? Journal of Marriage and Family, 72(1), 3-22. https://doi.org/10.1111/j.1741-3737.2009.00678.x

Biryukova, S. \& Tyndik, A. (2014). Who prefers zero? Attitudes towards childlessness in Russia and in its capital city. In European Population Conference 2014. Transitions: Opportunities and Threats. Budapest: EAPS, p. 312.

Bocknek, E.L., Brophy-Herb, H.E., Fitzgerald, H.E., Schiffman, R.F., \& Vogel, C. (2014). Stability of biological father presence as a proxy for family stability: Cross-racial associations with longitudinal development of emotion regulation in toddlerhood. Infant Mental Health Journal, 35(4), 309-321. https://doi.org/10.1002/imhj.21454

Borisenko, J.V., Belogaya, K.N., Morozova, I.S., \& Ott, T.O. (2016). Reproductive motivation in Russian women in the family context. Journal of Reproductive and Infant Psychology, 34(3), 224-234. https://doi.org/10.1080/02646838.2016.1156660 
Borisenko, Y.V. (2013). Adaptaciya metodiki Caregiving and Breadwinning Reflected Appraisal Inventory (CBIRAI) na russkij yazik [The Translation of Caregiving and Breadwinning Reflected Appraisal Inventory (CBIRAI) into Russian] Vector Nauki TGU, 2013, 4(15), 34-37.

Bouchard, G. (2012). Intergenerational Transmission and Transition to Fatherhood: A MediatedModeration Model of Paternal Engagement. Journal of Family Psychology, 2012, 26(5), 747-755. https://doi.org/10.1037/a0029391

Brutman, V.I., Pankratova, M.G., \& Enikopolov, S.N. (1994). Nekotorije resultati obsledovanija beremennikh zhentchin, otkazavshikhsja ot svoikh detey [Some results of the study of the pregnant women who leaved their new-born infants]. Voprosi psychologii, 5, 31-36.

Carlson, M.J. (2006). Family structure, father involvement, and adolescent behavioral outcomes. Journal of Marriage and Family, 68, 137-154. https://doi.org/10.1111/j.1741-3737.2006.00239.x

Coley, R., Votruba-Drzal, E., \& Schindler, H. (2009). Fathers' and mothers' parenting predicting and responding to adolescent sexual risk behaviors. Child Development, 80, 808-827. https://doi.org/10.1111/j.1467-8624.2009.01299.x

DeLuccie, M.F. (1996). Mothers: Influential agents in father-child relations. Genetic, Social, and General Psychology Monographs, 122, 287-307.

DePasquale, N., Polenick, C.A., Hinde, J., Bray, J.W., Zarit, S.H., Moen, P., Hammer, L.B., \& Almeida, D.M. (2016). Health Behavior Among Men With Multiple Family Roles: The Moderating Effects of Perceived Partner Relationship Quality. American Journal of Men's Health. https://doi.org/10.1177/1557988316660088

Deutsch, F., Servis, L., \& Payne, J. (2001). Paternal participation in child care and its effects on children's self-esteem and attitudes toward gendered roles. Journal of Family Issues, 22, 1000-1024. https://doi.org/10.1177/019251301022008003

Dobrykov, I.V. (2010). Perinatal'naja psichologija [Perinatal psychology]. Saint-Petersburg: Piter.

Doherty, W.J., Boss, P.G., LaRossa, R., Schumm, W.R., \& Steinmetz, S.K. (1993). Family theories and methods: A contextual approach. In P.G. Boss, W.J. Doherty, R. LaRossa, W.R. Schumm, \& S.K. Steinmetz (Eds.), Family theories and methods: A contextual approach. New York: Plenum Press. https://doi.org/10.1007/978-0-387-85764-0_1

Doucet, A. (2009). Dad and baby in the first year: Gendered responsibilities and embodiment. Annals of the American Academy of Political and Social Sciences, 624, 78-98. https://doi.org/10.1177/0002716209334069

Eggebeen, D.J., \& Knoester, C. (2001). Does fatherhood matter for men? Journal of Marriage and Family, 63, 381-393. https://doi.org/10.1111/j.1741-3737.2001.00381.x

El-Shadan, P., \& Schluter, J. (2015). Pacific father involvement and early child behavior outcomes: Findings from the Pacific Islands Families study. Journal of Child and Family Studies, 24(12), 3497-3505. https://doi.org/10.1007/s10826-015-0151-5

Erel, O., \& Burman, B. (1995). Interrelatedness of marital relations and parent-child relations: a meta-analytic review. Psychological Bulletin, 118(1), 108-132. https://doi.org/10.1037/00332909.118.1.108

Evans, E.A., Grella, C.E., \& Upchurch Dawn, M. (2017). Gender differences in the effects of childhood adversity on alcohol, drug, and polysubstance-related disorders. Social Psychiatry and Psychiatric Epidemiology, 52, 901-912. https://doi.org/10.1007/s00127-017-1355-3

Fagan, J., \& Lee, Y. (2016). Effects of father's early risk and resilience on paternal engagement with 5-yearolds. Journal of Family Relations, 1(5), 878-892. https://doi.org/10.1111/j.1741-3729.2012.00741.x

Filatova, A.Yu. (2010). Sovremettije podhodi k izucheniju problemi otcovstva v otechestvennoy psychologii [Modern approaches towards studying fathering in Russian psychology]. Izvestija visshikh uchebnikh zavedeniy, 4, 112-115.

Filippova, G.G. (2002). Psyhologiya materinstva [Psychology of motherhood]. Mosow: Isdatel'stvo Instituta psychoterapii [Institute of Psychotherapy Press]. 
Fthenakis, W.E. (2004). Bildungs- und Erziehungspläne für Kinder unter sechs Jahren - nationale und internationale Perspektiven [Educational and educational plans for children under the age of six - national and international perspectives.]. In: Faust, G., Götz, M., Hacker, H., Roßbach, H.-G. (Eds.), Anschlussfähige Bildungsprozesse im Elementar- und Primarbereich [Connectable educational processes in elementary and primary education]. Bad Heilbrunn/Obb.: Klinkhardt, S., 9-26.

Goldberg, W.A., Tan, E.T., \& Thorsen, K.L. (2009). Trends in Academic Attention to Fathers, 1930 2006. Fathering, 7(2), 159-179. https://doi.org/10.3149/fth.0702.159

Gurko, T.A. (1997). Roditelsvo v izmenjajutchikhsja soziokulturnikh uslovijakh [Parenting in a changing socio-cultural circumstances]. Sozis, 1, 72-79.

Gurko, T.A. (2003). Roditelstvo: sociologitcheskije aspekti [Parenting: sociological aspects]. Moskva: Zentr obtchechelovecheslikh zennostey.

Jeynes, W.H.(2015). A meta-analysis: The relationship between father involvement and student academic achievement. Urban Education, 50(4), 387-423. https://doi.org/10.1177/0042085914525789

Kletsina, I.S., \& Chikalova, E.A. (2013). Vzaimosviaz norn maskulinnosti i socialnikh predstavleniy o soderzhanii povediniya $\mathrm{v}$ ramkekh otcivskoy roli [Correlation between masculinity norms and social attitudes towards fathering]. Vestnik Leningradskogo gosudarstvennogo universiteta imeni A. S. Pushkina, 5(2), 24-35.

Kon, I.S. (2009). Muzhchina v menyajushemsya mire [Men in a changing world]. Moskva: Vremia.

Kotelchuck, M. (1976). The infant's relationship to the father: Experimental evidence In M.E. Lamb (Ed), The role of the father in child development (pp. 329-344). New York: Wiley.

Kwan, R., Kwok, S., \& Ling, C. (2015). The moderating role of parenting self-efficacy and co-parenting alliance on marital satisfaction among Chinese fathers and mothers. Journal of Family Studies, 24(12), 3506-3515. https://doi.org/10.1007/s10826-015-0152-4

Lamb, M.E. (2002). Infant-father attachments and their impact on child development. In C. TamisLeMonda \& N. Cabrera (Eds.), Handbook of father involvement: Multidisciplinary perspectives (pp. 93-117). Mahwah, NJ: Erlbaum.

Maurer, T.W., Pleck, J.H., \& Rane, T.R. (2001) Parental identity and reflected appraisals: Measurement and gender dynamics. Journal of Marriage and the Family, 63, 309-321. https://doi.org/10.1111/j.1741-3737.2001.00309.x

McBride, B.A, Dyer, W.J., \& Laxman, D. (2009). Father involvement and child outcomes: A longitudinal view. Paper presented at the Society for Research in Child Development Biennial Meeting, Denver, CO.

Miller, E.D. (2013). Why the father wound matters: Consequences for male mental health and the father-son relationship. Child Abuse Review, 22, 194-208. https://doi.org/10.1002/car.2219

Miller, W.B. (1986). Proception: an important fertility behavior. Demography, 23(4), 579-94. https://doi.org/10.2307/2061352

Nelson, D.A., Coyne, S.M., Swanson, S.M, Hart, C.H, \& Olsen, J.A. (2014). Parenting, relational aggression, and borderline personality features: Associations over time in a Russian longitudinal sample. Development and Psychopathology 26, 773-787. https://doi.org/10.1017/ S0954579414000388

Nelson, D.A., Hart, C.H., Keister, E., \& Piassetskaia, K. (2010). Russia. In M.H. Bornstein (Ed.), Handbook of cultural developmental science (pp. 409-428). New York: Psychology Press/Taylor \& Francis.

Ovcharova, R.V. (2003). Psychologitcheskoje soprovozhdenije roditelstva [Psychological assistance to parents]. Moskva: Izdtelstvo instituta psychoterapii.

Palkovitz, R. (2002). Involved fathering and child development: Advancing our understanding of good fathering. In C.S. Tamis-LeMonda \& N. Cabrera (Eds.), Handbook of father involvement: Multidisciplinary perspectives (pp. 119-140). Mahwah, N J: Laurence Erlbaum Associates.

Parke, R.D. (2002). Fathers and families. In M.H. Bornstein (Ed.), Handbook of parenting (2nd ed., Vol. 3, pp. 27-73). Mahwah, NJ: Laurence Erlbaum Associates. 
Pleck, J.H. (2010a). Fatherhood and Masculinity In M.E. Lamb (Ed.), The role of the father in child development (5rd ed., pp. 27-57). New York: Wiley.

Pleck, J.H. (2010b). Paternal Involvement Revised Conceptualization and Theoretical Linkages with Child Outcomes. In M.E. Lamb (Ed.), The role of the father in child development (5rd ed., pp. 58-93). NewYork: Wiley.

Pleck, J.H., \& Hofferth, S. (2008). Mother involvement as an influence on father involvement with early adolescents. Fathering, 6, 267-286. https://doi.org/10.3149/fth.0603.267

Polenick, C.A., DePasquale, N., Eggebeen, D.J., Zarit, S.H., \& Fingerman, K.L. (2016). Relationship quality between older fathers and middle-aged children: Implications for both parties' subjective well-being. Journals of Gerontology, Series B: Psychological Sciences and Social Sciences. https://doi.org/10.1093/geronb/gbw094

Radosteva, A.G. (2013). Vliyanije semeynich otnoshenij na roditel'skije ustanovki [The influence of family relations on parental attitudes] Fundamental'nije issledovanija [Fundamental Research], $8,1238-1242$.

Rominov, H., Giallo, R., \& Whelan, T.A. (2016). Fathers' postnatal distress, parenting self-efficacy, later parenting behavior, and children's emotional-behavioral functioning: A longitudinal study. Journal of Family Psychology, 30(8), 907-917. https://doi.org/10.1037/fam0000216

Roskam, I. Meunier, J., \& Stieveneart, M. (2016). Do mothers and fathers moderate the influence of each other's self-efficacy beliefs and parenting behaviors on children's extermalizing behavior? Journal of Child and Family Studies, 25(6), 2034-2045. https://doi.org/10.1007/ s10826-016-0365-1

Schaefer, E.S., \& Bell, R.Q. (1958) Development of a parental attitude research instrument. Child Development, 29, 339-361. https://doi.org/10.2307/1126348

Scoblo G.V., Baz, L.L., \& Lukovceva Z.V. (2004). Psychologiycheskoje zdorovije u detey doshkilnogo vozrasta ot materey s poslerodovoy derpessiey [Psychological health in children of mothers suffering postnatal depression]. Perinatalnaja psychologija i psychologija roditelstva, 7, 19-23.

Sigle-Rushton, W., \& McLanahan, S. (2004). Father absence and child well-being: A critical review. In D. Moynihan, T. Smeedling, \& L. Rainwater (Eds.), The future of the family (pp. 116-155). New York: Russell Sage Foundation.

Tasker, F. (2010). Same-sex parenting and child development: Reviewing the contribution of parental gender. Journal of Marriage and Family 72(1), 35-40. https://doi.org/10.1111/j.17413737.2009.00681.x

Varghese, C., \& Wachen, J. (2016). The determinants of father involvement and connections to children's literacy and language outcomes: A review of literature. Marriage and Family Review, 52(4), 331-359. https://doi.org/10.1080/01494929.2015.1099587

Wainright, J.L., \& Patterson, C.J. (2008). Peer relations among adolescents with female same sex parents. Developmental Psychology, 44, 117-126. https://doi.org/10.1037/0012-1649.44.1.117

Zakharova, E.I. (2011). Rol roditeley v gendernom vospitanii rebenka [The role of parents in child's gender socialization]. Molodoy ucheniy, 5-2, 140-142.

Original manuscript received July 27, 2018 Revised manuscript accepted February 01, 2019

First published online September 30, 2019

To cite this article: Borisenko, Yu.V., Evseenkova, E.V. (2019). Differences in Fathering among Russian Men Brought up with and without a Father. Psychology in Russia: State of the Art, 12(3), 105-120. DOI: 10.11621/pir.2019.0308 